\title{
Perbedaan Karakteristik Serta Tingkat Pelayanan Pejalan Kaki Pada Kawasan Pedestrian Di Kota Kendari (TPKPP)
}

\author{
Sri Fera Rahayu ${ }^{1)}$, Muh. Magribi ${ }^{2)}$, Jamal Harimudin ${ }^{3)}$, Ahmad Hidayat ${ }^{4)}$, Fitriani ${ }^{5)}$ \\ 1) Jurusan Geografi FITK Universitas Halu Oleo \\ ${ }^{2)}$ Fakultas Teknik Jurusan Sipil, Universitas Halu Oleo \\ 3)4)5) Jurusan Geografi FITK Universitas Halu Oleo \\ email: sriferarahayu@gmail.com
}

\begin{abstract}
Abstrak: Penelitian di kawasan perdagangan (Mall Mandonga) dan pendidikan (Universitas Halu Oleo) Penelitian ini telah dilaksanakan pada bulan Juli 2019 sampai Oktober 2019. Teknik pengumpulan data dilakukan dengan 1) survey melalui kuisioner dan wawancara terhadap responden 2) observasi pengamatan kegiatan fisik di lapangan 3) dokumentasi. Metode analisis data yang digunakan yaitu analisis karakteristik pejalan kaki, tingkat pelayanan jalan kaki dan tingkat kepuasan pejalan kaki kemudian dijelaskan secara deskriptif. Hasil penelitian menunjukkan bahwa tingkat pelayanan fasilitas pejalan kaki pada kawasan pendidikan di Universitas Halu Oleo adalah C dengan pejalan kaki memiliki arus stabil tetapi pejalan kaki dibatasi dalam memilih kecepatan dan sedikit ada konflik dengan tingkat pelayanan. Sedangkan tingkat pelayanan pejalan kaki pada kawasan perdagangan di Mall Mandonga adalah D dengan pejalan kaki memiliki arus mendekati tidak stabil sedangkan kecepatan masih bisa dikendalikan dan konflik yang terjadi di trotoar tersebut masih dapat ditolerir..
\end{abstract}

\section{Kata Kunci : Karakteristik, Pejalan Kaki, Tingkat Pelayanan, Kawasan Pedestrian}

\begin{abstract}
Abstrack: Research in the trade area (Mandonga Mall) and education (Halu Oleo University) This research was conducted in July 2019 to October 2019. Data collection techniques were carried out by 1) surveying through questionnaires and interviews with respondents 2) observing physical activity observations in the field 3) documentation. The data analysis method used is the analysis of pedestrian characteristics, the level of walking services and the level of pedestrian satisfaction then described descriptively. The results showed that the level of service of pedestrian facilities in the education area at Halu Oleo University is $\mathrm{C}$ with pedestrians having a steady flow but pedestrians are limited in choosing speed and there is little conflict with service levels. While the level of pedestrian services in the trade area at Mandonga Mall is D with pedestrians having an unstable approaching flow while speed can still be controlled and conflicts occurring on the sidewalk are still tolerable.
\end{abstract}

Keywords: Characteristics, Pedestrians, Service Level, Pedestrian Region. 


\section{PENDAHULUAN}

Pejalan kaki merupakan salah satu elemen yang sering kita temui di daerah pusat pertokoan, perdagangan, kampus serta berbagai kawasan lainnya karena sebagian besar kegiatan yang ada di tempat tersebut dilakukan dengan berjalan kaki. (Eddy, 2007). Oleh karena itu kebutuhan pejalan kaki terutama di pusat-pusat pertokoan dan kawasan lainnya sebagian tersebut diatas harus mendapat perhatian yang lebih. Salah satunya dengan menyediakan fasilitas pejalan kaki yang memadai di sekitar pusat pertokoan. Karena fasilitas tersebut sangat menentukan kelancaran pergerakan dari pejalan kaki. Kelancaran pergerakan dapat diketahui dengan melihat tingkat pelayanan dari masing-masing fasilitas pejalan kaki yang ada di sekitar daerah tersebut.

Pedestrian berasal dari bahasa Yunani pedos yang berarti kaki, sehingga pedestrian dapat diartikan sebagi pejalan kaki atau orang yang berjalan kaki, sedangkan ways jalan merupakan media diatas bumi yang memudahkan manusia dalam berjalan, Maka pedestrian dalam hal ini memiliki arti pergerakan atau perpindahan orang atau manusia dari satu tempat sebagai titik tolak ke tempat lain sebagai tujuan dengan menggunakan moda jalan kaki. Atau secara harfiah, pedestrian berarti person walking in the street, yang berarti orang yang berjalan di jalan (Iswanto 2006).

Pejalan kaki adalah orang yang melakukan aktifitas berjalan kaki dan merupakan salah satu unsur pengguna jalan (Keputusan Direktur Jendral Perhubungan Darat : SK.43/AJ 007/DRJD/97). Pejalan kaki harus berjalan pada bagian jalan yang diperuntukan bagi pejalan kaki, atau pada bagian pejalan kaki, atau pada bagian jalan yang paling kiri apabila tidak terdapat bagian jalan yang diperuntukan bagi pejalan kaki (PP No. 43 ,1993).

fasilitas pejalan kaki yang memadai di daerah tersebut sangat dibutuhkan karena konflik pejalan kaki di daerah 42 --- April tersebut bukan hanya disebabkan oleh pejalan kaki yang menuju atau meninggalkan toko tapi juga kendaraan motor, kendaraan pribadi, angkutan umum yang keluar masuk di daerah tersebut dan pada beberapa bagian yang dipenuhi pedagang kaki lima serta kendaraan parkir disekitar jalan menyebabkan para pejalan kaki kesulitan untuk melakukan pergerakan, sehingga dibutuhkan pelayanan agar pejalan kaki dan kendaraan bisa berjalanan sesuai fasilitas masingmasing. Berdasarkan uraian di atas, tujuan penelitian ini adalah untuk mengetahui karakteristik kinerja fasilitas pejalan kaki (arus pejalan kaki, kecepatan pejalan kaki dan kepadatan pejalan kaki), untuk mengetahui tingkat pelayanan fasilitas pedestrian dan untuk mengetahui tingkat kepuasan penggunaan fasilitas pada kawasan pendidikan dan kawasan perdagangan menggunakan analisis importance performance analysis.

\section{METODE PENELITIAN}

Penelitian ini akan dilaksanakan bulan Juli sampai Oktober 2019. Penelitian ini dilakukan di Kawasan Perdagangan Mall Mandonga dan Kawasan Pendidikan Universitas Halu Oleo. Peta lokasi penelitian dapat dilihat pada gambar berikut (Gambar 1).

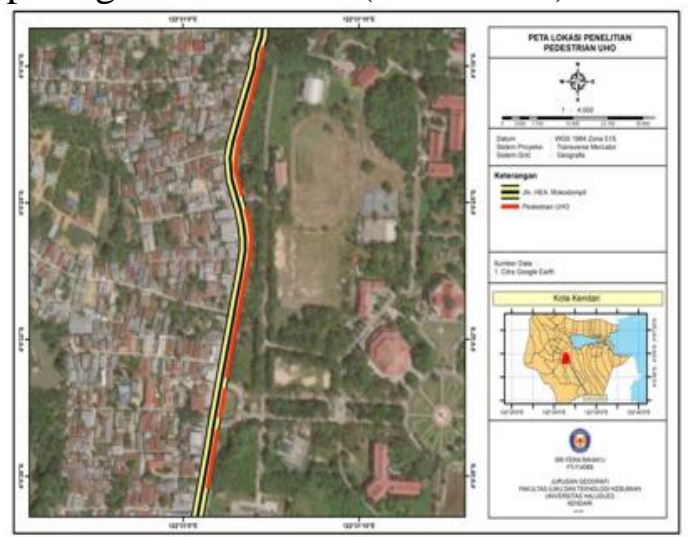

Gambar 1. Peta Lokasi Penelitian

\subsection{Populasi dan Sampel Penelitian}

Populasi dalam penelitian ini adalah pejalan kaki yang melintas pada penyebrangan jalan di Kawasan 
Perdagangan Mall Mandonga yaitu masyarakat pada umumnya dan di Kawasan Pendidikan Universitas Halu Oleo yaitu Mahasiswa. Teknik sampling yang digunakan untuk mengambil sampel responden pejalan kaki di jalan Kawasan Perdagangan Mall Mandonga dan jalan Kawasan Pendidikan Universitas Halu Oleo menggunakan teknik sampel accidental. Teknik sampling ini digunakan karena pejalan kaki yang melintas tidak diketahui identitas dan jumlah pastinya, sehingga perlu diambil sampel acak. Berikut adalah rumus untuk menentukan besar sampel (Margono, 2004 ):

$n=\frac{g z^{2} \cdot \mathrm{p}(1-p)}{E^{2}}$

Dimana :

- $\mathrm{n}$ merupakan sampel yang ingin dicari

- Z mengacu pada nilai $\mathrm{z}$ (tingkat kepercayaan). Pada studi ini tingkat kepercayaan yang digunakan adalah 95\%, sehingga nilai z-nya adalah 1,96 .

- p (1-p) merupakan variasi populasi yang dinyatakan dalam bentuk proporsi. Pada studi ini variasi populasi diasumsikan heterogen, maka proporsinya adalah 50:50.

- E adalah kesalahan sampel yang dikehendaki (sampling error). Studi ini menghendaki sampling error sebesar $10 \%$ atau 0,1 .

- $g$ merupakan estimasi nilai efek desain (design effect). Biasanya desain efek ini berbentuk pecahan 1.5, 1.8, dan lain sebagainya. Studi ini tidak menggunakan sampel acak stratifikasi ataupun sampel acak klaster, maka dari itu nilai desain efeknya adalah 1 .

Setelah besaran dari masing-masing variabel telah ditentukan, selanjutnya masing-masing angka dimasukan sesuai rumus dan dihasilkan jumlah sampel sebagai berikut :

$$
\begin{aligned}
n & =\frac{1 \cdot 1,96^{2} \cdot 0,5(1-0,5)}{0,1^{2} n} \\
& =96,04
\end{aligned}
$$

Hasil dari perhitungan dihasilkan sampel dengan angka 96,04, hasil dari perhitungan sampel kemudian akan dibulatkan sehingga jumlah sampel keseluruhan berjumlah 96 sampel. Sebagaimana pada metodologi pengumpulan data akan dilakukan penyebaran kuisioner untuk mengatur tingkat kepuasan pejalan kaki saat menggunakan fasilitas pedestrian, yang mana kuisioner ini akan ditujukan kepada responden yakni pejalan kaki yang berada di lokasi dan atau yang pernah mengunjungi kawasan studi, sehingga tahu keadaan pedestrian di Jalan Mall Mandonga dan Jalan Universitas Halu Oleo.

\subsection{Variabel Penelitian}

Variabel pengamatan yang akan digunakan dalam penelitian ini yaitu untuk mengetahui karakteristik pejalan kaki, tingkat pelayanan dan tingkat kepuasan pedestrian di Kawasan Perdagangan Mall Mandonga dan Kawasan Pendidikan Universitas Halu Oleo yaitu arus pejalan kaki, volume pejalan kaki, kerapatan pejalan kaki dan ruang pejalan kaki, keamanan, kenyamanan, keselamatan, kelancaran, dan kemudahan akses.

\subsection{Jenis Data}

\section{a. Data Primer}

Data primer adalah data yang diperoleh melalui pengumpulan data secara langsung dilapangan yaitu dengan cara melakukan observasi lapangan, wawancara, membagikan kuisioner dan melakukan pengambilan titik koordinat dengan bantuan alat GPS (Sugiyono, 2005). Survei lapangan ini bertujuan mencocokkan keakuratan data yang ada dengan keadaan di lapangan. Data primer yang dibutuhkan dalam penelitian ini yaitu arus pejalan kaki, volume pejalan kaki, kepadatan pejalan kaki, ruang pejalan kaki serta persepsi responden atas kinerja fasilitas pejalan kaki.

\section{b. Data Sekunder}

Data sekunder adalah data yang diperoleh dari instansi-instansi terkait tentang penelitian ini (Amalia, 2013). Selain itu, data sekunder juga dapat 
diperoleh dengan melakukan studi pustaka melalui buku, penelitian-penelitian sebelumnya, serta dari jurnal maupun artikel. Data yang dibutuhkan pada penelitian ini diantaranya, peta administrasi Kota Kendari, data infrastruktur seperti kawasan pendidikan, dan pusat perbelanjaan.

\section{HASIL DAN PEMBAHASAN}

\subsection{Karakteristik Pejalan Kaki}

\section{a. Arus Pejalan Kaki}

Arus pejalan kaki adalah jumlah pejalan kaki yang melewati suatu penapang tertentu, yang biasanya dinyatakan dengan jumlah pejalan kaki per satuan waktu (pejalan, permenit).

Data arus pejalan kaki diperoleh berdasarkan survey di lapangan selama 4 hari dalam 4 minggu pada 2 lokasi berbeda sepanjang trotoar (trotoar Mall Mandonga dan Universitas Halu Oleo) Lokasi pertama ada di depan Universitas Halu Oleo kedua dan di depan Mall Mandonga.

\section{1) Universitas Halu Oleo}

Berikut ini adalah hasil perhitungan jumlah arus pejalan kaki pada hari Sabtu, tanggal 17 November 2019 dari empat segmen (trotoar) yang dimana segmen (trotoar) pertama yang diberi simbol S1 berada di depan Bank BRI, segmen (trotoar) kedua yang diberi simbol S2 berada di depan Tumaka Net, segmen (trotoar) 3 yang diberi simbol S3 berada di depan Foto Copy Kejora sampai di depan Warkop Santai Kendari, dan segmen (trotoar) 4 yang diberi simbol S4 berada di depan Aking Cell sampai di depan Lorong Salangga pada satu lokasi pengamatan, yaitu pada lokasi pengamatan arus pejalan kaki di depan Kampus Universitas Halu Oleo dengan interval waktu 15 menit.

Tabel 1. Arus Pejalan Kaki, pukul 10:00 - 11:00 di Universitas Halu Oleo

\begin{tabular}{|c|c|c|c|c|c|c|c|}
\hline \multirow[b]{2}{*}{ Jam } & \multicolumn{5}{|c|}{ Jumlah Pejalan Kaki } & \multirow{2}{*}{$\begin{array}{l}\text { Waktu } \\
\text { Pengamatan } \\
\text { (Menit) }\end{array}$} & \multirow{2}{*}{$\begin{array}{l}\text { Arus Pejalan Kaki } \\
\text { (orang / menit) }\end{array}$} \\
\hline & S1 & $\mathrm{S} 2$ & S3 & S4 & $\begin{array}{l}\text { Jumlah } \\
\text { (Orang) }\end{array}$ & & \\
\hline \multirow{4}{*}{$\begin{array}{c}10.00- \\
11.00\end{array}$} & 2 & 1 & 3 & 2 & 8 & 15 & 0,53 \\
\hline & 3 & 1 & 3 & 2 & 9 & 15 & 0,6 \\
\hline & 1 & 2 & 2 & 2 & 7 & 15 & 0,46 \\
\hline & 1 & 2 & 1 & 0 & 4 & 15 & 0,26 \\
\hline JUMLAH & 7 & 6 & 9 & 6 & 28 & 60 & 0,46 \\
\hline
\end{tabular}

Sumber : Hasil olah data lapangan (2019).

Pada Tabel 1 di atas bahwa jumlah pejalan kaki pada pukul 10:00 sampai 11:00 jumlah pejalan kaki terbanyak berada disegmen 3 dengan jumlah 9 orang dikarenakan segmen tersebut merupakan segmen terpanjang dan kebanyakan mahasiswa melewati segmen tersebut. Arus pejalan kaki pada pukul 10:00 sampai 11:00 adalah 46 orang pejalan kaki persatuan menit. Dalam interval waktu 1 jam 40 menit terdapat 46 orang pejalan kaki pada 4 segmen pengamatan.

Hasil perhitungan jumlah arus pejalan kaki pada hari Sabtu, tanggal 17 November 2019 dari empat segmen (trotoar) yang dimana segmen (trotoar) pertama yang diberi simbol S1 berada di depan Bank BRI, segmen (trotoar) kedua yang diberi simbol S2 berada di depan Tumaka Net, segmen (trotoar) 3 yang diberi simbol S3 berada di depan Foto Copy Kejora sampai di depan Warkop Santai Kendari, dan segmen (trotoar) 4 yang diberi simbol S4 berada di depan Aking Cell sampai di depan Lorong Salangga pada satu lokasi pengamatan, yaitu pada lokasi pengamatan arus pejalan kaki di depan Kampus Universitas Halu Oleo dengan interval waktu 15 menit. 
Tabel 2. Arus Pejalan Kaki, pukul 11:00 - 12:00 di Universitas Halu Oleo

\begin{tabular}{cccccccc}
\hline \multirow{2}{*}{ Jam } & \multicolumn{4}{c}{ Jumlah Pejalan Kaki } & Waktu Pengamatan & $\begin{array}{c}\text { Arus Pejalan Kaki } \\
\text { (orang / menit) }\end{array}$ \\
\cline { 2 - 6 } & S1 & S2 & S3 & S4 & $\begin{array}{c}\text { Jumlah } \\
\text { (Orang) }\end{array}$ & (Menit) & 0,33 \\
\hline \multirow{3}{*}{$11.00-12.00$} & 1 & 1 & 1 & 5 & 15 & 0,53 \\
& 3 & 2 & 1 & 2 & 8 & 15 & 0,8 \\
\cline { 2 - 6 } & 4 & 1 & 4 & 3 & 12 & 15 & 1 \\
\hline JUMLAH & 3 & 5 & 5 & 2 & 15 & 15 & 0,66 \\
\hline
\end{tabular}

Sumber : Hasil olah data lapangan (2019).

Pada Tabel 2 terlihat bahwa jumlah pejalan kaki pada pukul 11:00 sampai 12:00 jumlah pejalan kaki terbanyak berada disegmen 1 dengan jumlah 12 orang dan yang paling sedikit berada disegmen 4 yaitu 8 orang. Arus pejalan kaki pada pukul 11:00 sampai 12:00 adalah 66 orang pejalan kaki per satuan menit. Dalam interval waktu 1 jam 40 menit terdapat 66 orang pejalan kaki pada 4 segmen pengamatan.

Hasil perhitungan jumlah arus pejalan kaki pada hari Sabtu, tanggal 17 November 2019 dari empat segmen (trotoar) yang dimana segmen (trotoar) pertama yang diberi simbol S1 berada di depan Bank BRI, segmen (trotoar) kedua yang diberi simbol S2 berada di depan Tumaka Net, segmen (trotoar) 3 yang diberi simbol S3 berada di depan Foto Copy Kejora sampai di depan Warkop Santai Kendari, dan segmen (trotoar) 4 yang diberi simbol S4 berada di depan Aking Cell sampai di depan Lorong Salangga pada satu lokasi pengamatan, yaitu pada lokasi pengamatan arus pejalan kaki di depan Kampus Universitas Halu Oleo dengan interval waktu 15 menit.

Tabel 3. Arus Pejalan Kaki, pukul 12:00 - 13:00 di Universitas Halu Oleo

\begin{tabular}{|c|c|c|c|c|c|c|c|}
\hline \multirow{2}{*}{ Jam } & \multicolumn{5}{|c|}{ Jumlah Pejalan Kaki } & \multirow{2}{*}{$\begin{array}{c}\text { Waktu Pengamatan } \\
\text { (Menit) }\end{array}$} & \multirow{2}{*}{$\begin{array}{l}\text { Arus Pejalan Kaki } \\
\text { (orang / menit) }\end{array}$} \\
\hline & $\mathrm{S} 1$ & $\mathrm{~S} 2$ & S3 & $\mathrm{S} 4$ & Jumlah (Orang) & & \\
\hline \multirow{4}{*}{$12.00-13.00$} & 3 & 2 & 2 & 4 & 11 & 15 & 0,73 \\
\hline & 2 & 3 & 3 & 2 & 10 & 15 & 0,66 \\
\hline & 1 & 0 & 0 & 1 & 2 & 15 & 0,13 \\
\hline & 1 & 2 & 1 & 1 & 5 & 15 & 0,33 \\
\hline JUMLAH & 7 & 7 & 6 & 8 & 28 & 60 & 0,46 \\
\hline
\end{tabular}

Sumber : Hasil olah data lapangan (2019).

Pada Tabel 3 menunjukkan jumlah pejalan kaki pada pukul 12:00 sampai 13:00 jumlah pejalan kaki terbanyak berada disegmen 4 dengan jumlah 8 orang dan yang paling sedikit berada disegmen 3 yaitu 6 orang. Arus pejalan kaki pada pukul 12:00 sampai 13:00 adalah 46 orang pejalan kaki per satuan menit. Dalam interval waktu 1 jam 40 menit terdapat 46 orang pejalan kaki pada 4 segmen pengamatan.
Hasil perhitungan jumlah arus pejalan kaki pada hari Sabtu, tanggal 17 November 2019 dari empat segmen (trotoar) yang dimana segmen (trotoar) pertama yang diberi simbol S1 berada di depan Bank BRI, segmen (trotoar) kedua yang diberi simbol S2 berada di depan Tumaka Net, segmen (trotoar) 3 yang diberi simbol S3 berada di depan Foto Copy Kejora sampai di depan Warkop Santai Kendari, dan segmen (trotoar) 4 yang diberi simbol S4 berada di depan 
Aking Cell sampai di depan Lorong Salangga pada satu lokasi pengamatan, yaitu pada lokasi pengamatan arus pejalan kaki di depan Kampus Universitas Halu Oleo dengan interval waktu 15 menit.

Tabel 4. Arus Pejalan Kaki, pukul 13:00 - 14:00 di Universitas Halu Oleo

\begin{tabular}{|c|c|c|c|c|c|c|c|}
\hline \multirow[b]{2}{*}{ Jam } & \multicolumn{5}{|c|}{ Jumlah Pejalan Kaki } & \multirow[b]{2}{*}{$\begin{array}{l}\text { Waktu Pengamatan } \\
\text { (Menit) }\end{array}$} & \multirow[b]{2}{*}{$\begin{array}{l}\text { Arus Pejalan Kaki } \\
\text { (orang / menit) }\end{array}$} \\
\hline & $\mathrm{S} 1$ & $\mathrm{~S} 2$ & $\mathrm{~S} 3$ & $\mathrm{~S} 4$ & $\begin{array}{l}\text { Jumlah } \\
\text { (Orang) }\end{array}$ & & \\
\hline \multirow{4}{*}{$13.00-14.00$} & 2 & 2 & 0 & 1 & 5 & 15 & 0,33 \\
\hline & 3 & 1 & 1 & 1 & 6 & 15 & 0,4 \\
\hline & 2 & 0 & 1 & 2 & 5 & 15 & 0,33 \\
\hline & 1 & 1 & 1 & 2 & 5 & 15 & 0,33 \\
\hline JUMLAH & 8 & 4 & 3 & 6 & 21 & 60 & 0,35 \\
\hline
\end{tabular}

Sumber : Hasil olah data lapangan (2019).

Pada Table 4 menunjukkan bahwa jumlah pejalan kaki pada pukul 13:00 sampai 14:00 jumlah pejalan kaki terbanyak berada disegmen 1 dengan jumlah 8 orang dan yang paling sedikit berada disegmen 3 yaitu 3 orang. Arus pejalan kaki pada pukul 13:00 sampai 14:00 adalah 35 orang pejalan kaki per satuan menit. Dalam interval waktu 1 jam 40 menit terdapat 35 orang pejalan kaki pada 4 segmen pengamatan.

Hasil perhitungan jumlah arus pejalan kaki pada hari Sabtu, tanggal 17 November 2019 dari empat segmen (trotoar) yang dimana segmen (trotoar) pertama yang diberi simbol S1 berada di depan Bank BRI, segmen (trotoar) kedua berada yang diberi simbol S2 di depan Tumaka Net, segmen (trotoar) 3 yang diberi simbol S3 berada di depan Foto Copy Kejora sampai di depan Warkop Santai Kendari, dan segmen (trotoar) 4 yang diberi simbol S4 berada di depan Aking Cell sampai di depan Lorong Salangga pada satu lokasi pengamatan, yaitu pada lokasi pengamatan arus pejalan kaki di depan Kampus Universitas Halu Oleo dengan interval waktu 15 menit.

Tabel 5. Arus Pejalan Kaki, pukul 14:00 - 15:00 di Universitas Halu Oleo

\begin{tabular}{|c|c|c|c|c|c|c|c|}
\hline \multirow[b]{2}{*}{ Jam } & \multicolumn{5}{|c|}{ Jumlah Pejalan Kaki } & \multirow{2}{*}{$\begin{array}{c}\text { Waktu Pengamatan } \\
\text { (Menit) }\end{array}$} & \multirow{2}{*}{$\begin{array}{l}\text { Arus Pejalan Kaki } \\
\quad \text { (orang / menit) }\end{array}$} \\
\hline & $\mathrm{S} 1$ & S2 & S3 & $\mathrm{S} 4$ & $\begin{array}{l}\text { Jumlah } \\
\text { (Orang) }\end{array}$ & & \\
\hline \multirow{4}{*}{$14.00-15.00$} & 2 & 2 & 1 & 1 & 6 & 15 & 0,4 \\
\hline & 1 & 3 & 1 & 2 & 7 & 15 & 0,46 \\
\hline & 2 & 1 & 2 & 1 & 8 & 15 & 0,53 \\
\hline & 3 & 1 & 1 & 1 & 8 & 15 & 0,53 \\
\hline JUMLAH & 8 & 7 & 5 & 5 & 29 & 60 & 0,48 \\
\hline
\end{tabular}

Sumber : Hasil olah data lapangan (2019).

Berdasarkan tabel di atas bahwa jumlah pejalan kaki pada pukul 14:00 sampai 15:00 jumlah pejalan kaki terbanyak berada disegmen 1 dengan jumlah 8 orang dan yang paling sedikit berada disegmen 3 dan 4 yaitu 5 orang. Arus pejalan kaki pada pukul 14:00 sampai 15:00 adalah 48 orang pejalan kaki per 46 --- April satuan menit. Dalam interval waktu 1 jam 40 menit terdapat 48 orang pejalan kaki pada 4 segmen pengamatan.

Berikut ini adalah hasil perhitungan jumlah arus pejalan kaki pada hari Sabtu, tanggal 17 November 2019 dari empat segmen (trotoar) yang dimana segmen (trotoar) pertama yang diberi simbol S1 
berada di depan Bank BRI, segmen (trotoar) kedua yang diberi simbol S2 berada di depan Tumaka Net, segmen (trotoar) 3 yang diberi simbol S3 berada di depan Foto Copy Kejora sampai di depan Warkop Santai Kendari, dan segmen (trotoar) 4 yang diberi simbol S4 berada di depan Aking Cell sampai di depan Lorong Salangga pada satu lokasi pengamatan, yaitu pada lokasi pengamatan arus pejalan kaki di depan Kampus Universitas Halu Oleo dengan interval waktu 15 menit.

Tabel 6. Arus Pejalan Kaki, pukul 15:00 - 16:00 di Universitas Halu Oleo

\begin{tabular}{|c|c|c|c|c|c|c|c|}
\hline \multirow[b]{2}{*}{ Jam } & \multicolumn{5}{|c|}{ Jumlah Pejalan Kaki } & \multirow{2}{*}{$\begin{array}{c}\text { Waktu } \\
\text { Pengamatan } \\
\text { (Menit) }\end{array}$} & \multirow{2}{*}{$\begin{array}{l}\text { Arus Pejalan Kaki } \\
\text { (orang / menit) }\end{array}$} \\
\hline & $\mathrm{S} 1$ & $\mathrm{~S} 2$ & S3 & $\mathrm{S} 4$ & $\begin{array}{l}\text { Jumlah } \\
\text { (Orang) }\end{array}$ & & \\
\hline \multirow{4}{*}{$15.00-16.00$} & 3 & 2 & 10 & 1 & 16 & 15 & 1,06 \\
\hline & 1 & 2 & 8 & 1 & 12 & 15 & 0,8 \\
\hline & 2 & 5 & 5 & 5 & 17 & 15 & 1,13 \\
\hline & 3 & 6 & 7 & 4 & 20 & 15 & 1,33 \\
\hline JUMLAH & 9 & 15 & 30 & 11 & 65 & 60 & 1,08 \\
\hline
\end{tabular}

Sumber : Hasil olah data lapangan (2019).

Berdasarkan tabel di atas bahwa jumlah pejalan kaki pada pukul 15:00 sampai 16:00 jumlah pejalan kaki terbanyak berada disegmen 3 dengan jumlah 30 orang dan yang paling sedikit berada disegmen 1 yaitu 9 orang. Arus pejalan kaki pada pukul 15:00 sampai 16:00 adalah 108 orang pejalan kaki per satuan menit. Dalam interval waktu 1 jam 40 menit terdapat 108 orang pejalan kaki pada 4 segmen pengamatan.

Berikut ini adalah hasil perhitungan jumlah arus pejalan kaki pada hari Sabtu, tanggal 17 November 2019 dari empat segmen (trotoar) yang dimana segmen (trotoar) pertama yang diberi simbol S1 berada di depan Bank BRI, segmen (trotoar) kedua yang diberi simbol S2 berada di depan Tumaka Net, segmen (trotoar) 3 yang diberi simbol S3 berada di depan Foto Copy Kejora sampai di depan Warkop Santai Kendari, dan segmen (trotoar) 4 yang diberi simbol S4 berada di depan Aking Cell sampai di depan Lorong Salangga pada satu lokasi pengamatan, yaitu pada lokasi pengamatan arus pejalan kaki di depan Kampus Universitas Halu Oleo dengan interval waktu 15 menit.

Tabel 7. Arus Pejalan Kaki, pukul 16:00 - 17:00 di Universitas Halu Oleo

\begin{tabular}{|c|c|c|c|c|c|c|c|}
\hline \multirow[b]{2}{*}{ Jam } & \multicolumn{5}{|c|}{ Jumlah Pejalan Kaki } & \multirow{2}{*}{$\begin{array}{c}\text { Waktu } \\
\text { Pengamatan } \\
\text { (Menit) }\end{array}$} & \multirow{2}{*}{$\begin{array}{l}\text { Arus Pejalan Kak } \\
\text { (orang / menit) }\end{array}$} \\
\hline & S1 & $\mathrm{S} 2$ & $\mathrm{~S} 3$ & S4 & $\begin{array}{l}\text { Jumlah } \\
\text { (Orang) }\end{array}$ & & \\
\hline \multirow{4}{*}{$16.00-17.00$} & 3 & 9 & 5 & 5 & 22 & 15 & 1,46 \\
\hline & 2 & 6 & 8 & 9 & 25 & 15 & 1,66 \\
\hline & 5 & 5 & 6 & 5 & 21 & 15 & 1,4 \\
\hline & 3 & 5 & 11 & 9 & 28 & 15 & 1,86 \\
\hline JUMLAH & 13 & 25 & 30 & 28 & 96 & 60 & 1,6 \\
\hline
\end{tabular}

Sumber : Hasil olah data lapangan (2019).

Berdasarkan tabel di atas bahwa jumlah pejalan kaki pada pukul 16:00 sampai 17:00 jumlah pejalan kaki terbanyak berada disegmen 3 dengan jumlah 30 orang dan yang paling sedikit berada disegmen 1 yaitu 13 orang. Arus 
pejalan kaki pada pukul 16:00 sampai 17:00 adalah 160 orang pejalan kaki per satuan menit. Dalam interval waktu 1 jam 40 menit terdapat 160 orang pejalan kaki pada 4 segmen pengamatan.

Berikut ini adalah hasil perhitungan jumlah arus pejalan kaki pada hari Sabtu, tanggal 17 November 2019 dari empat segmen (trotoar) yang dimana segmen (trotoar) pertama yang diberi simbol S1 berada di depan Bank BRI, segmen (trotoar) kedua yang diberi simbol S2 berada di depan Tumaka Net, segmen (trotoar) 3 yang diberi simbol S3 berada di depan Foto Copy Kejora sampai di depan Warkop Santai Kendari, dan segmen (trotoar) 4 yang diberi simbol S34berada di depan Aking Cell sampai di depan Lorong Salangga pada satu lokasi pengamatan, yaitu pada lokasi pengamatan arus pejalan kaki di depan Kampus Universitas Halu Oleo dengan interval waktu 15 menit.

Tabel 8. Arus Pejalan Kaki, pukul 17:00 - 18:00 di Universitas Halu Oleo

\begin{tabular}{|c|c|c|c|c|c|c|c|}
\hline \multirow[b]{2}{*}{ Jam } & \multicolumn{5}{|c|}{ Jumlah Pejalan Kaki } & \multirow{2}{*}{$\begin{array}{c}\text { Waktu } \\
\text { Pengamatan } \\
\text { (Menit) }\end{array}$} & \multirow{2}{*}{$\begin{array}{l}\text { Arus Pejalan Kaki } \\
\quad \text { (orang / menit) }\end{array}$} \\
\hline & $\mathrm{S} 1$ & $\mathrm{~S} 2$ & S3 & $\mathrm{S} 4$ & $\begin{array}{l}\text { Jumlah } \\
\text { (Orang) }\end{array}$ & & \\
\hline \multirow{4}{*}{$17.00-18.00$} & 1 & 9 & 12 & 10 & 32 & 15 & 2,13 \\
\hline & 2 & 7 & 10 & 8 & 27 & 15 & 1,8 \\
\hline & 1 & 5 & 15 & 10 & 31 & 15 & 2,06 \\
\hline & 2 & 10 & 17 & 6 & 35 & 15 & 2,33 \\
\hline JUMLAH & 6 & 31 & 54 & 34 & 125 & 60 & 2,08 \\
\hline
\end{tabular}

Sumber : Hasil olah data lapangan (2019).

Berdasarkan tabel di atas bahwa jumlah pejalan kaki pada pukul 1700 sampai 18:00 jumlah pejalan kaki terbanyak berada disegmen 3 dengan jumlah 54 orang dan yang paling sedikit berada disegmen 1 yaitu 6 orang. Arus pejalan kaki pada pukul 17:00 sampai 18:00 adalah 208 orang pejalan kaki per satuan menit. Dalam interval waktu 1 jam 40 menit terdapat 208 orang pejalan kaki pada 4 segmen pengamatan.

Berikut ini adalah hasil perhitungan jumlah arus pejalan kaki pada hari Sabtu, tanggal 17 November 2019 dari empat .Tabel 9. Arus Pejalan Kaki, per jam di Universitas Halu Oleo

\begin{tabular}{|c|c|c|c|c|c|c|c|}
\hline \multirow[b]{2}{*}{ Jam } & \multicolumn{5}{|c|}{ Jumlah Pejalan Kaki } & \multirow{2}{*}{$\begin{array}{l}\text { Waktu Pengamatan } \\
\text { (Menit) }\end{array}$} & \multirow{2}{*}{$\begin{array}{l}\text { Arus Pejalan Kak } \\
\quad \text { (orang / menit) }\end{array}$} \\
\hline & $\mathrm{S} 1$ & $\mathrm{~S} 2$ & S3 & $\mathrm{S} 4$ & $\begin{array}{c}\text { Jumlah } \\
\text { (Orang) }\end{array}$ & & \\
\hline $10.00-11.00$ & 7 & 6 & 9 & 6 & 28 & 60 & 0,46 \\
\hline $11.00-12.00$ & 12 & 9 & 11 & 8 & 40 & 60 & 0,66 \\
\hline $12.00-13.00$ & 7 & 7 & 6 & 8 & 28 & 60 & 0,46 \\
\hline $13.00-14.00$ & 8 & 4 & 3 & 6 & 21 & 60 & 0,35 \\
\hline $14.00-15.00$ & 8 & 7 & 5 & 5 & 29 & 60 & 0,48 \\
\hline $15.00-16.00$ & 9 & 15 & 30 & 11 & 65 & 60 & 1,08 \\
\hline $16.00-17.00$ & 13 & 25 & 30 & 28 & 96 & 60 & 1,6 \\
\hline $17.00-18.00$ & 6 & 31 & 54 & 34 & 125 & 60 & 2,08 \\
\hline JUMLAH & 70 & 104 & 148 & 106 & 432 & 480 & 0,9 \\
\hline
\end{tabular}

Sumber : Hasil olah data lapangan (2019). 
Berdasarkan tabel di atas bahwa jumlah pejalan kaki pada pukul 10:00 sampai 18:00 jumlah pejalan kaki terbanyak berada disegmen 3 dengan jumlah 148 orang dan yang paling sedikit berada disegmen 1 yaitu 70 orang. Arus pejalan kaki pada pukul 10:00 sampai 18:00 adalah 9 orang pejalan kaki per satuan menit. Atau rata-rata jumlah pejalan kakiselama delapan jam adalah 9 orang per 10 menit pada 4 segmen pengamatan.

Arus jumlah pejalan kaki diperoleh dari jumlah pejalan kaki setiap jam dibagi waktu pengamatan setiap jamnya dalam hal ini delapan jam. Berikut adalah rumus untuk menentukan besar sampel (mannering dan kilareski,1988):

$$
\begin{aligned}
& \mathrm{Q}=\mathrm{N} / \mathrm{T} \\
& \mathrm{Q}=432 / 480
\end{aligned}
$$

$$
\begin{aligned}
\mathrm{Q} & =0,9 \text { orang } / \text { menit } \\
& =9 \text { orang per } 10 \text { menit }
\end{aligned}
$$

Berikut ini adalah hasil diagram perhitungan jumlah arus pejalan kaki pada hari Sabtu, tanggal 17 November 2019 dari empat segmen (trotoar) yang dimana segmen (trotoar) pertama berada di depan Bank BRI, segmen (trotoar) kedua berada di depan Tumaka Net, segmen (trotoar) 3 berada di depan Foto Copy Kejora sampai di depan Warkop Santai Kendari, dan segmen (trotoar) 4 berada di depan Aking Cell sampai di depan Lorong Salangga pada satu lokasi pengamatan, yaitu pada lokasi pengamatan arus pejalan kaki di depan Kampus Universitas Halu Oleo dengan interval waktu 15 menit.

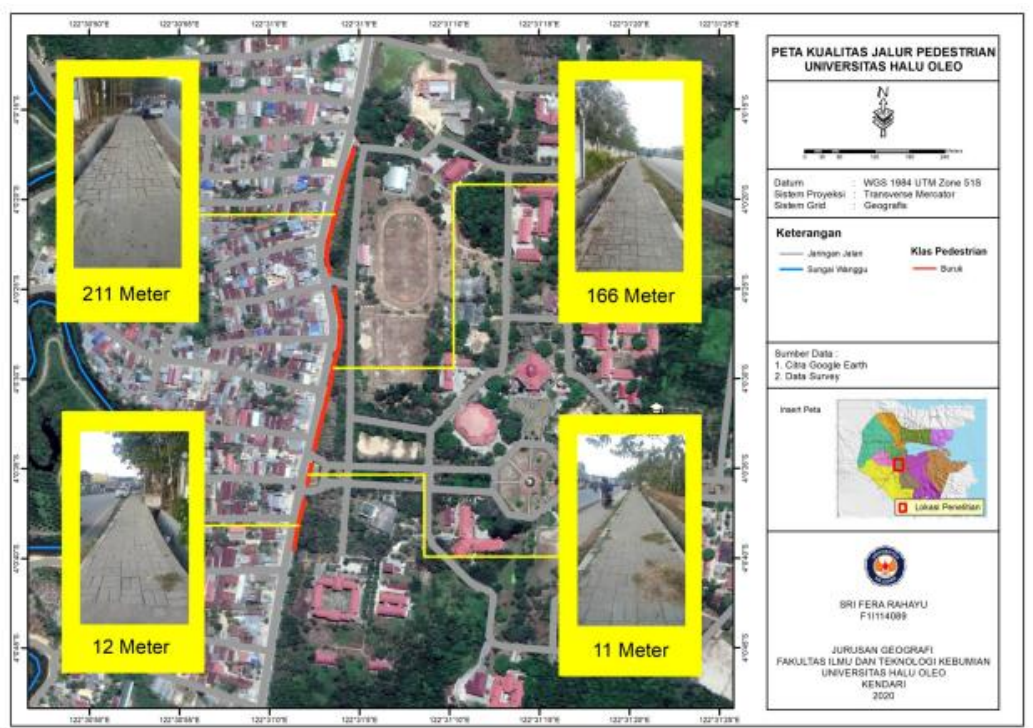

Gambar 2. Peta Kawasan Pedestrian UHO 
| Vol.5 | No.1| 2021

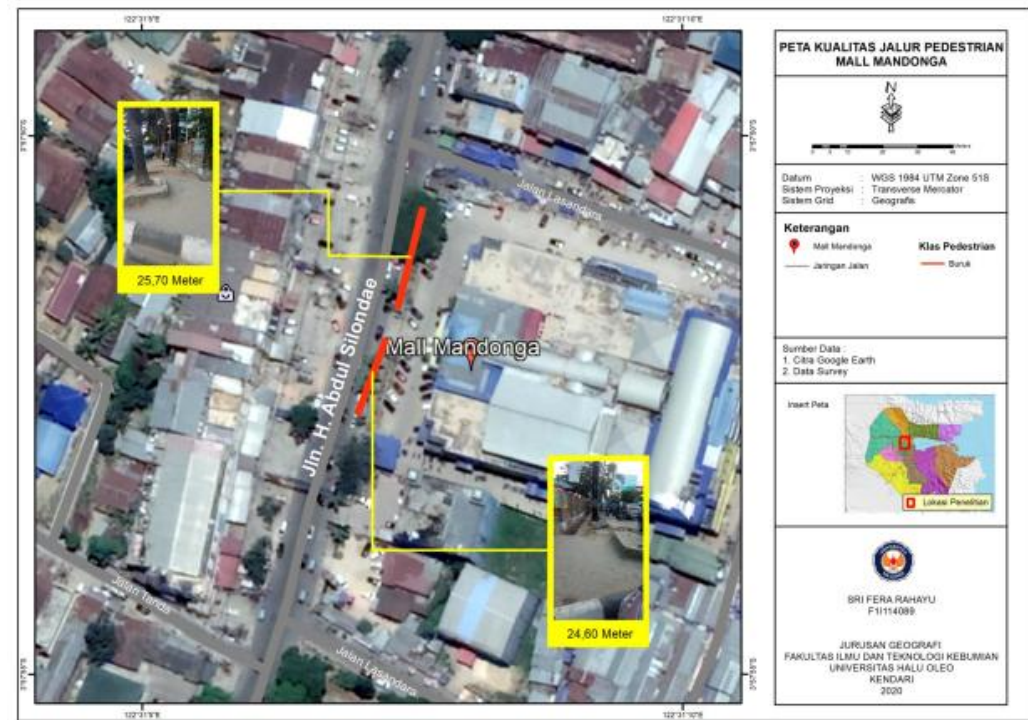

Gambar 3. Peta Kawasan Pedestrian Mall Mandonga

\section{KESIMPULAN}

Simpulan dari hasil penelitian tentang Perbedaan Karakteristik Pejalan Kaki Serta Tingkat Pelayanan Pejalan Kaki Pada Beragam Tipe Kawasan Pedestrian di Kota Kendari yaitu sebagai berikut: (1) Karakteristik kinerja fasilitas pejalan kaki terbagi menjadi arus pejalan kaki, kecepatan pejalan kaki dan kepadatan pejalan kaki. Arus pejalan kaki pada kawasan pendidikan di Universitas Halu Oleo adalah 0,09 orang/menit sedangkan arus pejalan kaki pada kawasan perdagangan di Mall Mandonga adalah 0,67 orang/menit. Kecepatan pejalan kaki di Universitas Halu Oleo pada segmen satu adalah $31,91 \mathrm{~m} /$ menit, pada segmen dua adalah $24,27 \mathrm{~m} /$ menit, pada segmen tiga adalah $59 \mathrm{~m} /$ menit, pada segmen empat adalah 50,70 $\mathrm{m} / \mathrm{menit}$, sedangkan kecepatan pejalan kaki di Mall Mandonga pada segemen satu adalah $65,12 \mathrm{~m} /$ menit, pada segmen dua adalah $74,37 \mathrm{~m} /$ menit. Kepadatan pejalan kaki di Universitas Halu Oleo pada segmen satu adalah 0,02 pejalan $\mathrm{kaki} / \mathrm{m}^{2}$, pada segmen dua adalah 0,03 pejalan $\mathrm{kaki} / \mathrm{m}^{2}$, pada segmen tiga adalah 0,015 pejalan $\mathrm{kaki} / \mathrm{m}^{2}$, pada segmen empat adalah 0,017 pejalan $\mathrm{kaki} / \mathrm{m}^{2}$, sedangkan kecepatan pejalan kaki di Mall Mandonga pada segemen satu adalah 0,01 pejalan $\mathrm{kaki} / \mathrm{m}^{2}$, pada segmen dua adalah 0,009 pejalan $\mathrm{kaki} / \mathrm{m}^{2}$. (2) Tingkat pelayanan fasilitas pejalan kaki pada kawasan pendidikan di Universitas Halu Oleo adalah $\mathrm{C}$ dengan pejalan kaki memiliki arus stabil tetapi pejalan kaki dibatasi dalam memilih kecepatan dan sedikit ada konflik dengan tingkat pelayanan. Sedangkan tingkat pelayanan pejalan kaki pada kawasan perdagangan di Mall Mandonga adalah D dengan pejalan kaki memiliki arus mendekati tidak stabil sedangkan kecepatan masih bisa dikendalikan dan konflik yang terjadi di trotoar tersebut masih dapat ditolerir. (3) Tingkat kepuasan penggunaan fasilitas pada kawasan pendidikan dan kawasan perdagangan adalah pada Kuadran A menunjukkan faktor atau atribut yang dianggap penting oleh pejalan kaki namun tidak terlaksanakan dengan baik, Kuadran B menunjukkan faktor atau atribut yang dianggap penting dan memuaskan pejalan kaki, Kuadran C menunjukkan faktor yang dianggap kurang penting oleh pejalan kaki dan tidak terlaksanakan dengan baik, dan Kuadran D menunjukkan faktor atau atribut yang dianggap kurang penting bagi pejalan kaki namun dilaksanakan dengan berlebihan oleh pembuat trotoar. 


\section{DAFTAR PUSTAKA}

Amalia, Riski, 2013, Pengertian Data Sekunder Dan Data Primer Menurut Para Ahlih

(http://riski.ilearning.me/babii/.diakses pada Maret 2014).

Eddy, E., 2007, Fasilitas Pejalan Kaki Di Kampus UGM Yogyakarta. Yogyakarta: Universitas Gajah Mada.

Iswanto, D., 2006, Pengaruh ElemenElemen Pelengkap Jalur Pedestrian Terhadap Kenyamanan Pejalan Kaki (Studi Kasus : Penggaal Jalan Pandanaran, Dimulai Dari Jalan Randusari Hingga Kawasan Tugu
Muda), Jurnal Ilmiah Perancangan Kota Dan Permukiman, Vol.5, No.1, p. 21-29.

Margono, 2004, Metodologi Penelitian Pendidikan. Jakarta: Rineka Cipta.

Mannering, F. L and Kilareski, W. P. 1988, Principles of Highway Engineering and Traffic Analysis. New York: Wiley.

Peraturan Pemerintah Republik Indonesia Nomor 43 Tahun 1993 Tentang Prasarana dan Lalulintas Jalan, Lembar Negara Republik Indonesia Nomor 3529.

Sugiyono, 2005, Memahami Penelitian Kualitatif, Bandunng: Alfabeta. 
JAGAT (Jurnal Geografi Aplikasi Dan Teknologi) ISSN : 2549-9181 | e-ISSN : 2684-6705 | Vol.5 | No.1| 2021

52 --- April 